\title{
Effects of the Yangjing Capsule Extract on Steroidogenesis and Apoptosis in Mouse Leydig Cells
}

\author{
Dalin Sun, ${ }^{1}$ Yugui Cui, ${ }^{2}$ Baofang Jin, ${ }^{1}$ Xindong Zhang,, ${ }^{1}$ Xiaoyu Yang, ${ }^{2}$ and Chao Gao ${ }^{2}$ \\ ${ }^{1}$ Institute of Andrology, Nanjing University of Chinese Medicine, Nanjing 210046, China \\ ${ }^{2}$ State Key Laboratory of Reproductive Medicine, Clinical Center of Reproductive Medicine, and the First Affiliated Hospital, \\ Nanjing Medical University, Nanjing 210029, China
}

Correspondence should be addressed to Baofang Jin, hexiking@126.com

Received 12 May 2012; Revised 4 September 2012; Accepted 3 October 2012

Academic Editor: Cheppail Ramachandran

Copyright (C) 2012 Dalin Sun et al. This is an open access article distributed under the Creative Commons Attribution License, which permits unrestricted use, distribution, and reproduction in any medium, provided the original work is properly cited.

\begin{abstract}
Objectives. This study aimed to explore the effect and mechanism of Yangjing capsule on testosterone secretion in mouse Leydig tumor cells (MLTC-1). Methods. MLTC-1 cells were treated with the Yangjing capsule extract for $24 \mathrm{~h}$. The testosterone level in medium was measured by radioimmunoassay. The expression of steroidogenic enzymes (StAR, CYP11A1, and HSD3B) in the cells was examined using real-time RT-PCR and immunoblotting. Additionally, MLTC-1 cells were treated for $48 \mathrm{~h}$ in a serumfree medium. The cell viability was measured by MTT assay. The cell cycle and apoptosis were analyzed using flow cytometry. The expression of activated caspase- 3 was analyzed using RT-PCR and a colorimetric protease assay. Results. The Yangjing capsule extract increased testosterone production and the expression of StAR, CYP11A1, and HSD3B mRNAs and proteins compared with the control. H89 significantly inhibited these effects. The medicine improved the viability of MLTC-1 cells, decreased the number of cells in G0/G1 phase, and increased the number of cells in S-phase, as well as prevented cell apoptosis by inhibiting caspase3. Conclusion. The Yangjing capsule can stimulate MLTC-1 cells to secrete testosterone and may be an alternative treatment for diseases characterized by insufficient testosterone production.
\end{abstract}

\section{Introduction}

Testosterone, the major circulating androgen, plays important roles in sexual differentiation, secondary sex characteristics, reproductive function, and sexual function [1]. Male hypogonadism, also known as testosterone deficiency syndrome (TDS), is often associated with impaired puberty, impotence, gynecomastia, and infertility or lowered spermatogenesis $[2,3]$. Some men in midlife and old age experience late onset of hypogonadism ( $\mathrm{LOH}$ ). The incidence rates are $13 \%$ for men aged $40-49$ years, $30 \%$ for men aged $50-59$ years, and $47 \%$ for men over 70 years. Testosterone replacement therapy (TRT) may provide a wide range of benefits for hypogonadism, improving libido and sexual function, fertility, bone density, muscle mass, and quality of life $[4,5]$. However, TRT involves the direct administration of an exogenous hormone. With this treatment, the androgen level in the serum is superphysiological and unstable. If injected with a testosterone oiling agent, the peak concentration of androgen in the serum is very high, and the hormonal fluctuation may be difficult for the patient to bear. Furthermore, TRT could increase the risk of prostate cancer, worsen the symptoms of benign prostatic hypertrophy, sleep apnea and congestive heart failure, cause liver toxicity, and promote gynecomastia, infertility, and skin diseases [4].

Formulations of traditional Chinese medicine, especially those intended for kidney support, have shown significant advantages for the treatment of male hypogonadism through multiple mechanisms of action as well as interactions with multiple targets, including opsonic action $[6,7]$. The Yangjing capsule, which is composed of Herba Epimedii Brevicornus, Radix Rehmanniae Preparata, Rhizoma Polygonati Sibirici, Placenta Hominis, Angelica sinensis, and other components, primarily acts by stimulating the kidney. It has been suggested for the treatment of diseases of the reproductive system due to its endogenous effect on androgen production, including male infertility, sexual dysfunction, and LOH. In our previous study, we found that the Yangjing capsule 
improved sperm motility, concentration, and DNA integrity in infertile males, and it improved the libido and erections of patients with male sexual disorders [8-10]. We proposed that the Yangjing capsule may promote androgen synthesis and hormonal balance, which could be the basis for the treatment of male infertility and sexual dysfunction.

Testosterone is primarily produced by testicular Leydig cells, which is regulated by $\mathrm{LH}[11]$. By binding to the membrane LH receptor, LH induces cAMP synthesis in Leydig cells. cAMP catalyzes PKA synthesis, and PKA transports cholesterol from the cytoplasmic pool to the mitochondria to promote steroidogenesis by steroidogenic enzymes (CYP11A1, HSD3B, and so on) and StAR [12, 13]. Additionally, steroidogenesis is also dependent on the number and activity of Leydig cells [13]. The number of Leydig cells is maintained at equilibrium due to the balance between proliferation and apoptosis [14]. Excessive apoptosis may produce adverse effects, such as testosterone deficiency $[13,15,16]$.

In this study, we explored the role of the Yangjing capsule in regulating steroidogenesis in Leydig cells and investigated its potential mechanism to provide evidence in supporting of treatment of male infertility and hypogonadism with the Yangjing capsule.

\section{Materials and Methods}

2.1. Chemicals. RPMI 1640 medium, fetal bovine serum and lyophilized trypsin-EDTA were obtained from GIBCO BRL (Grand Island, NY, USA). 3-[4,5-Dimethylthiazolyl-2]-2,5-diphenyltetrazolium bromide (MTT), dimethyl sulfoxide (DMSO), human chorionic gonadotropin (hCG), N-(2-[p-bromocinnamylamino] ethyl)5-isoquinolinesulfonamide hydrochloride (H89), diethylpyrocarbonate (DEPC), sodium dodecyl sulfate (SDS), and Tris/HCl were purchased from Sigma (St. Louis, MO, USA). The caspase-3 colorimetric protease assay kit and the whole protein extraction kit were purchased from Keygen (Keygen Biotech. Co. Ltd., Nanjing, China). Trizol reagent, PrimeScript RT Master Mix, and SYBR Green PCR Master Mix reagent kits were obtained from TaKaRa (TaKaRa Biotechnology, Dalian, China). The primers were synthesized by Invitrogen Life Tech (Carlsbad, CA, USA). The goat polyclonal anti-CYP11A1 and rabbit polyclonal anti-HSD3B antibodies were purchased from Santa Cruz Biotechnology (Santa Cruz, CA, USA). The rabbit polyclonal anti-StAR antibody was obtained from Abcam (Cambridge Science Park, Cambridge, UK). The mouse polyclonal anti-GAPDH antibody and HRP-conjugated secondary antibodies were purchased from Bioworld (St. Louis Park, MN, USA). Enhanced chemiluminescence was obtained from Amersham Biosciences (Uppsala, Sweden).

2.2. The Yangjing Capsule Extract. The Yangjing capsule is composed of 11 traditional Chinese drugs: 13.3\% Herba Epimedii Brevicornus, 6.7\% Rhizoma Polygonati Sibirici, 6.7\% Radix Rehmanniae preparata, 10\% Radix Astragali
Mongolici, 6.7\% Placenta Hominis, 6.7\% Semen Astragali Complanati, 10\% Radix Angelicae Sinensis, 6.7\% Hirudo, 6.7\% Semen Litchi, 13.3\% Semen Vaccariae Segetalis, and 13.3\% Concha Ostreae (calcined). The Yangjing capsule extract was prepared based on the methods described by Kao et al. and $\mathrm{Hu}$ et al. $[17,18]$. The content of the Yangjing capsule ( $3.33 \mathrm{~g}$, equivalent to $10 \mathrm{~g}$ of crude drug) was extracted with $333 \mathrm{~mL}$ of distilled water and subsequently subjected to ultrasonic extraction for $45 \mathrm{~min}$. The supernatant was collected. The precipitate was dissolved and extracted in a similar manner. The two solutions were combined and centrifuged at $13,000 \mathrm{~g}$ and $4^{\circ} \mathrm{C}$ for $30 \mathrm{~min}$ to collect the supernatant, which was concentrated to $100 \mathrm{~mL}$ with a rotary evaporator at $60^{\circ} \mathrm{C}$. The final concentration of the Yangjing capsule extract corresponded to $100 \mathrm{mg} / \mathrm{mL}$ of the crude herbal dose. No hCG or estradiol was detected in the extract by radioimmunoassay (RIA), which could avoid the influence of hCG and estradiol contained in Placenta Hominis on the MLTC- 1 cells. The $\mathrm{pH}$ of the extract was adjusted to 7.0, and the extract was sterilized by filtration on a super clean bench and stored at $-70^{\circ} \mathrm{C}$ until use.

2.3. Cell Culture and Treatment. The mouse Leydig tumor cells (MLTC-1) were derived from a transplantable Leydig cell tumor carried in C57BL/6 mice. MLTC-1 cells can produce testosterone with or without hCG. Therefore, MLTC-1 is a good cellular model for studying steroidogenesis and regulation. MLTC-1 cells were obtained from the Cell Institute of Shanghai (Shanghai, China) and cultured in RPMI-1640 medium that contained $2.05 \mathrm{mM}$ L-glutamine, $10 \%$ heat-inactivated fetal bovine serum, $100 \mathrm{IU} / \mathrm{mL}$ penicillin, and $100 \mathrm{~g} / \mathrm{mL}$ streptomycin in $5 \% \mathrm{CO}_{2}$ at $37^{\circ} \mathrm{C}$. The Yangjing capsule extract was diluted to low, medium, and high concentrations with RPMI-1640 without serum. The Yangjing capsule was administered to male infertility patients at a dose of 2 pills, tid. This dosage is equivalent to $9 \mathrm{~g}$ of crude drug. If the mean volume of one adult is approximately $0.06 \mathrm{~m}^{3}$, the distribution of medicine can be estimated as $0.15 \mathrm{mg} / \mathrm{mL}$. Therefore, we chose the concentration of $0.1 \mathrm{mg} / \mathrm{mL}$ as the middle dose for treating the cells. Then, this dose was varied 10-fold to investigate a range of concentrations corresponding to $0.01,0.1$, and $1 \mathrm{mg} / \mathrm{mL}$ of the crude herbal dose.

2.4. Hormone Assays. MLTC- 1 cells were treated with the Yangjing capsule extract $(0.01-1 \mathrm{mg} / \mathrm{mL})$ over $24 \mathrm{~h}$ in $5 \%$ serum with or without hCG. The hCG group was used as a positive control. hCG can increase testosterone production through stimulation of the PKA signaling pathway in Leydig cells [19]. When we combined the Yangjing capsule extract with hCG, additive or synergistic effects were observed. To determine whether the Yangjing capsule extract acts through the PKA pathway to regulate steroidogenesis in MLTC-1 cells, the PKA pathway inhibitor $\mathrm{H} 89$ was used to treat cells for $24 \mathrm{~h}$. The culture medium was subsequently collected, and testosterone was analyzed by radioimmunoassay (RIA). The minimum detectable concentration of testosterone was 
$0.2 \mathrm{ng} / \mathrm{mL}$. The inter- and intra-assay coefficients of variation were $<10 \%$ and $<15 \%$, respectively.

2.5. RNA Isolation and Quantitative Real-Time RT-PCR Analysis of Steroidogenic Enzymes. Cells at a density of $4 \times$ $10^{5} /$ well were plated in 6 -well plates and treated with the Yangjing capsule extract in 5\% serum for $24 \mathrm{~h}$. Following stimulation by hCG for $4 \mathrm{~h}$, the total RNA was extracted using Trizol reagent. The extracted RNA was measured by spectrometry at an $\mathrm{OD}_{260 / 280}$ and reverse transcribed into cDNA in a total volume of $20 \mu \mathrm{L}$ with PrimeScript RT Master Mix. All of the RT-PCR reactions were performed with an ABI Prism 7300 Sequence Detection System (Perkin Elmer Applied Biosystems, Foster City, CA, USA) using SYBR Green PCR Master Mix reagent kits. The housekeeping gene GAPDH was selected as the internal control. The primer sequences were as follows: GAPDH, sense: $5^{\prime}$-AGG TTG TCT CCT GCG ACT TCA-3' and antisense: $5^{\prime}$-GGG TGG TCC AGG GTT TCT TAC T-3', 186 bp; StAR, sense: 5' -CCA CCT GCA TGG TGC TTC A-3' and antisense: $5^{\prime}$-TTG GCG AAC TCT ATC TGG GTC TG-3', $142 \mathrm{bp}$; CYP11A1, sense: $5^{\prime}$ GAC CGA ATC GTC CTA AAC CA-3' and antisense: $5^{\prime}$ GGA ACA TCT GGT AGA CAG CAT TG-3', 278 bp; and HSD3B, sense: 5'-GTG GGG CTT CTG CCT TGA T-3' and antisense: $5^{\prime}$-GGT TTT CTG CTT GGC TTC CTC-3', $235 \mathrm{bp}$. The reactions were performed at $94^{\circ} \mathrm{C}$ for $3 \mathrm{~min}$ followed by 40 cycles at $94^{\circ} \mathrm{C}$ for $10 \mathrm{~s}, 60^{\circ} \mathrm{C}$ for $31 \mathrm{~s}$, and $72^{\circ} \mathrm{C}$ for $30 \mathrm{~s}$. A melting curve analysis was performed to confirm the products. The relative abundances of the target mRNAs were calculated using the $2^{-\Delta \Delta C t}$ method. The data were expressed as the percentage of control (100\%).

2.6. Protein Extraction and Western Blot Analysis. Cells were seeded in $60 \mathrm{~mm}$ dishes at a density of $1 \times 10^{6} /$ well, and the Yangjing capsule extract in 5\% serum was added for $24 \mathrm{~h}$ or for $4 \mathrm{~h}$ with activation of hCG. The cells were harvested, washed three times with precooled PBS, and treated with cell lysis buffer for Western blot analysis. After centrifugation at $12,000 \mathrm{~g}$ at $4^{\circ} \mathrm{C}$ for $20 \mathrm{~min}$, the supernatants were collected and stored at $-70^{\circ} \mathrm{C}$ until analysis. The concentrations of protein were determined using the bicinchoninic acid assay [20]. The proteins were normalized to $50 \mu \mathrm{g} / \mathrm{lane}$, separated by $12 \%$ sodium dodecyl sulfate polyacrylamide gel electrophoresis (SDS-PAGE), and subsequently transferred to nitrocellulose membranes. After treatment with blocking solution (5\% skim milk powder in Tris-buffered saline) at $37^{\circ} \mathrm{C}$ for $1 \mathrm{~h}$, the membranes were incubated overnight with the primary antibodies goat polyclonal anti-CYP11A1 (1: 500), rabbit polyclonal anti-StAR (1: 500), rabbit polyclonal anti-HSD3B (1: 500), or mouse polyclonal anti-GAPDH (1: 2000) at $4^{\circ} \mathrm{C}$. After washing with TBS three times, the membranes were incubated with HRP-conjugated secondary antibodies (1: 5000) at $37^{\circ} \mathrm{C}$ for $1 \mathrm{~h}$ and examined using enhanced chemiluminescence. The relative protein levels in each sample were normalized to the levels of GAPDH to standardize the variations in loading. Densitometric analyses of the scanned immunoblotting images were performed using a Quantity One image system. The data are expressed as a percentage of the control $(100 \%)$.

2.7. Cell Viability Assay. The viability and proliferation of the cells were assessed by the MTT assay, which is based on the reduction of MTT by the mitochondrial dehydrogenase of intact cells to form a purple formazan product [21]. The cells were seeded in a 96-well plate at a density of $5 \times 10^{3} / 100$ $\mu \mathrm{L}$ and routinely incubated for $24 \mathrm{~h}$ at $37^{\circ} \mathrm{C}$ prior to use. After $24 \mathrm{~h}$, the cells were treated with different concentrations $(0.01-1 \mathrm{mg} / \mathrm{mL})$ of the Yangjing capsule extract without serum for different time intervals $(24,48$ and $72 \mathrm{~h}$ ). After treatment, the media that contained the Yangjing capsule extract were carefully removed by aspiration. Subsequently, $20 \mu \mathrm{L}$ of $5 \mathrm{mg} / \mathrm{mL}$ MTT in cell culture medium was added to each well and incubated for $4 \mathrm{~h}$. To dissolve the resulting formazan crystals, $150 \mu \mathrm{L}$ of DMSO solution was added to each well, and the plates were brachytely vibrated in an incubator for $10 \mathrm{~min}$. The amount of formazan was determined by measuring the absorbance $(A)$ value at a wavelength of $490 \mathrm{~nm}$ with respect to $630 \mathrm{~nm}$ using a microplate reader (Bio-Rad, CA, USA).

\subsection{Analysis of Cell Cycle and Apoptosis Using Flow Cytometry.} For cell cycle analysis, $4 \times 10^{5}$ cells/well were seeded in 6-well multidishes and incubated until they reached the logarithmic phase. The cells were rinsed twice with PBS and cultured with different concentrations $(0.01-1 \mathrm{mg} / \mathrm{mL})$ of the Yangjing capsule extract without serum for $48 \mathrm{~h}$. They were subsequently trypsinized and centrifuged at $600 \mathrm{~g}$ at $4^{\circ} \mathrm{C}$ for $5 \mathrm{~min}$. The supernatant was removed, and the cells were resuspended in $1 \mathrm{~mL}$ of PBS. An aliquot of $3 \mathrm{~mL}$ of cold ethanol was added, and the mixture was kept at $-20^{\circ} \mathrm{C}$ for $24 \mathrm{~h}$. After centrifugation at $600 \mathrm{~g}$ at $4^{\circ} \mathrm{C}$ for $5 \mathrm{~min}$, the pellet was treated with $2 \mathrm{mg} / \mathrm{mL}$ RNase A at $37^{\circ} \mathrm{C}$ for $30 \mathrm{~min}$ and stained with $50 \mu \mathrm{g} / \mathrm{mL}$ propidium iodide containing $0.1 \%$ Triton X-100 and $0.02 \mathrm{mg} / \mathrm{mL}$ EDTA. The percentage of cells in each stage of the cell cycle was determined using CellQuest software (Becton Dickinson, NJ, USA). The proliferation index $(\mathrm{PI})$ was calculated using the following formula: $P I=$ $(S+G 2 / M) /(G 0 / G 1+S+G 2 / M)$.

The procedure for cell apoptosis analysis was the same as above until the supernatant was removed and the cells were resuspended in PBS at a density of $1 \times 10^{6} / \mathrm{mL}$. The suspension was subsequently added to FITC-labeled Annexin $\mathrm{V}$ and stained with propidium iodide. Flow cytometric analysis was performed using a FACSAria flow cytometer (Becton Dickinson, NJ, USA).

2.9. Caspase-3 mRNA and Protein Activity Assay. Cells at a density of $4 \times 10^{5} /$ well were plated in 6-well plates and treated with the Yangjing capsule extract without serum for $48 \mathrm{~h}$ to activate caspase- 3 . Then, the RNA was extracted and reverse-transcribed. The conditions for the RT-PCR reactions were same as above. The primer sequences were as follows: GAPDH, sense: $5^{\prime}$-AGG TTG TCT CCT GCG ACT TCA- $3^{\prime}$ and antisense: $5^{\prime}$-GGG TGG TCC AGG GTT TCT TAC T-3', $186 \mathrm{bp}$; and caspase-3, sense: 5'-ATG GGA GCA 
AGT CAG TGG AC-3' and antisense: 5'-CGT ACC AGA GCG AGA TGA CA-3', $136 \mathrm{bp}$. The activity of the caspase-3 protein was detected using a caspase- 3 colorimetric protease assay kit. The caspase- 3 colorimetric assay was based on the hydrolysis of the peptide substrate acetyl-Asp-Glu-Val-Aspp-nitroanilide (Ac-DEVD-pNA) by caspase-3, resulting in the release of the p-nitroaniline (pNA) moiety, which had a high absorbance at $405 \mathrm{~nm}$ [22]. The cells were seeded at a density of $1 \times 10^{6} /$ well in 60 -mm dishes and treated with the Yangjing capsule extract without serum for $48 \mathrm{~h}$ to stimulate caspase- 3 activity. The cells were harvested and washed three times with ice-cold PBS. After centrifugation at $1,000 \mathrm{~g}$ for $3 \mathrm{~min}$, the cells were lysed by sonication on ice for $20 \mathrm{~min}$ in a chilled cell lysis buffer. Subsequently, the lysates were centrifuged at $10,000 \mathrm{~g}$ at $4^{\circ} \mathrm{C}$ for $1 \mathrm{~min}$, and the supernatants were collected. The protein concentration was determined and adjusted for the cell lysis buffer. From each sample, $50 \mu \mathrm{L}$ of protein were solubilized in twofold reaction buffer. After incubation at $37^{\circ} \mathrm{C}$ for $4 \mathrm{~h}$, the value for every sample was read at $405 \mathrm{~nm}$ in a microtiter plate reader.

2.10. Statistical Analysis. The data were expressed as the means \pm SD from at least three independent experiments. Statistically significant differences between the groups were determined by one-way ANOVA followed by the least significance difference (LSD) or with $t$-test comparison procedure. The statistical significance was set at $P<0.05$.

\section{Results}

3.1. Effects of the Yangjing Capsule Extract on Testosterone Production with or without hCG. MLTC-1 cells were treated with the Yangjing capsule extract for $24 \mathrm{~h}$ combined with or without $0.1 \mathrm{U} / \mathrm{mL}$ of hCG for $4 \mathrm{~h}$ (Figure 1). Testosterone production significantly increased after treatment with the Yangjing capsule extract at concentrations greater than $0.01 \mathrm{mg} / \mathrm{mL}$ without hCG $(P<0.05)$ and at concentrations greater than $0.1 \mathrm{mg} / \mathrm{mL}$ with hCG $(P<0.05)$ when compared with the controls.

3.2. Effects of the Yangjing Capsule Extract on the Expression of StAR, CYP11A1, and HSD3B mRNAs and Proteins. Three key enzymes (StAR, CYP11A1, and HSD3B) were chosen to examine the mechanism by which the Yangjing capsule extract regulates steroidogenesis. Figure 2(a) showed that the expression levels of StAR mRNA and protein were increased significantly by the Yangjing capsule extract at concentrations of $1 \mathrm{mg} / \mathrm{mL}$ and greater than $0.01 \mathrm{mg} / \mathrm{mL}$, respectively $(P<0.05)$. Figure $2(\mathrm{~b})$ showed that the expression of CYP11A1 mRNA and protein were markedly increased by the Yangjing capsule extract at doses of greater than 0.1 and $0.01 \mathrm{mg} / \mathrm{mL}$, respectively $(P<0.05)$. Figure 2(c) showed that the Yangjing capsule extract induced the expression of HSD3B mRNA and protein in a dosedependent manner $(P<0.05)$. As expected, hCG stimulated the expression of StAR, CYP11A1, and HSD3B mRNAs and proteins.

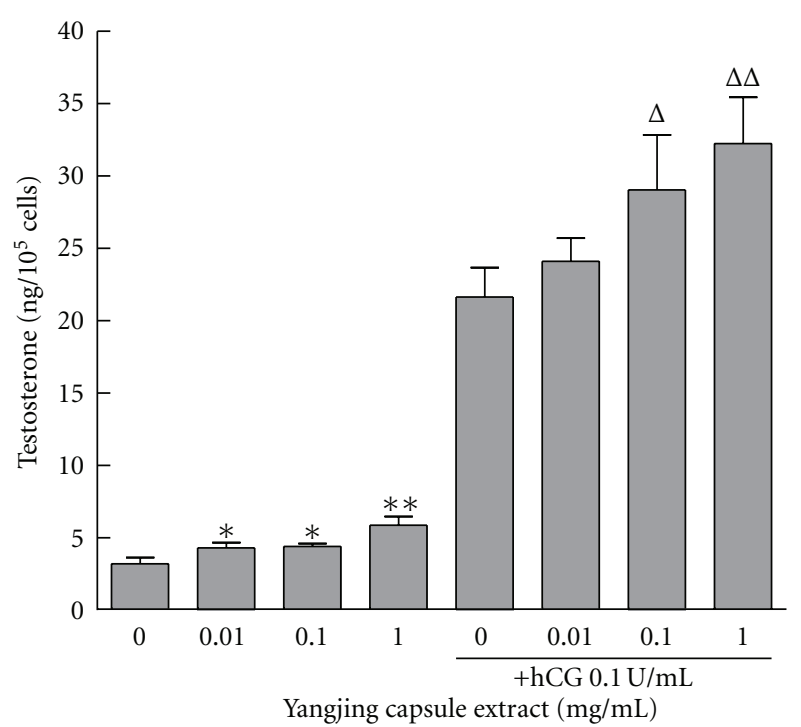

FIgURE 1: Effects of the Yangjing capsule extract on testosterone production in MLTC- 1 cells. The Yangjing capsule extract $(0,0.01$, $0.1,1 \mathrm{mg} / \mathrm{mL}$ ) was used to treat MLTC- 1 cells for $24 \mathrm{~h}$ combined with or without hCG stimulation for $4 \mathrm{~h}$. The results are given as the means \pm SD from three independent experiments. Compared with the control without hCG, ${ }^{*} P<0.05,{ }^{* *} P<0.01$; compared with the control treated only with hCG, ${ }^{\Delta} P<0.05,{ }^{\Delta \Delta} P<0.01$.

3.3. Effects of the Yangjing Capsule Extract on Testosterone Production Was Inhibited by H89. To explore whether the Yangjing capsule extract acts on the PKA pathway, the H89, a PKA inhibitor, was added for an incubation period of $24 \mathrm{~h}$. H89 ( $5 \mu \mathrm{M}$ and $10 \mu \mathrm{M})$ caused a dose-dependent decrease in testosterone production that was stimulated by the Yangjing capsule extract (Figure 3). Moreover, H89 (10 $\mu \mathrm{M})$ significantly inhibited Yangjing-stimulated testosterone production by $37 \%(P<0.01)$.

3.4. Effects of the Yangjing Capsule Extract on Cell Viability. The effect of the Yangjing capsule extract on the cell viability was both dose and time dependent (Figure 4). The absorption values significantly increased after treatment with the Yangjing capsule extract $(0.1$ and $1 \mathrm{mg} / \mathrm{mL})$ for $48 \mathrm{~h}$ and $72 \mathrm{~h}(P<0.05)$. The results showed that the Yangjing capsule extract improved the cell viability of MLTC-1 cells after treatment for 48 and $72 \mathrm{~h}$ at doses above $0.1 \mathrm{mg} / \mathrm{mL}$. Therefore, we chose the time point of $48 \mathrm{~h}$ to observe the effect of the Yangjing capsule extract on the cell cycle and apoptosis.

3.5. Effects of the Yangjing Capsule Extract on Cell Cycle. Flow cytometry analysis of MLTC-1 cells incubated with the Yangjing capsule extract for $48 \mathrm{~h}$ showed the changes in the percentage of cells at different stages, G0/G1, S, and G2/M (Figures 5(a) and 5(b)). The number of cells in G0/G1 phase significantly decreased, while the number of cells in $\mathrm{S}$ phase increased in groups treated with concentrations higher than $0.1 \mathrm{mg} / \mathrm{mL}(P<0.05)$. However, the percentage of 

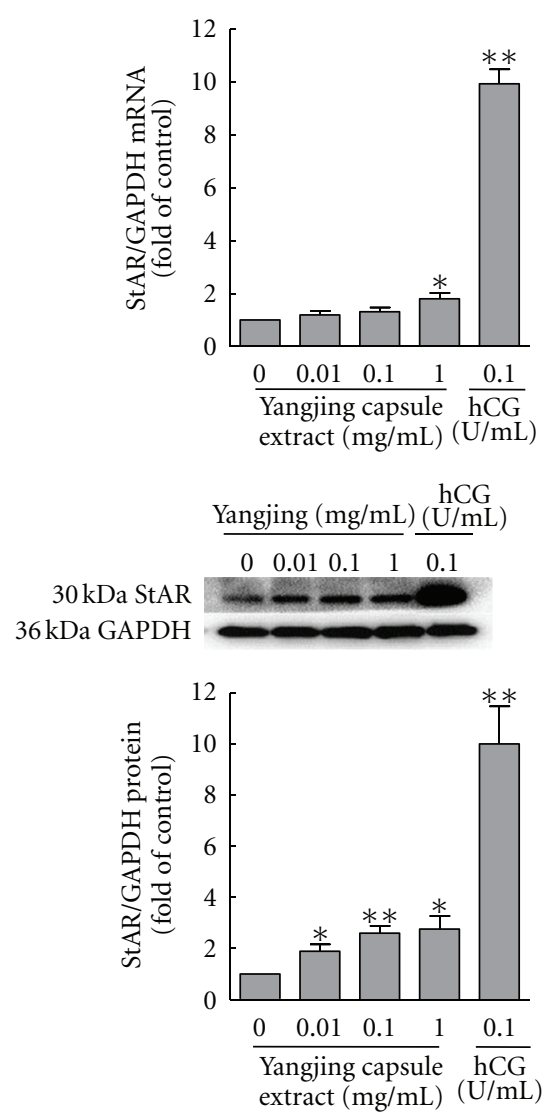

(a)

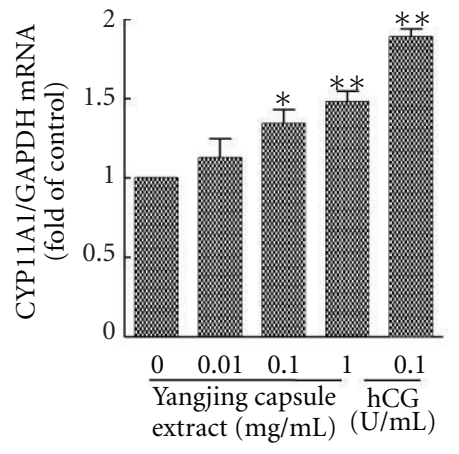

Yangjing $(\mathrm{mg} / \mathrm{mL}) \underline{\mathrm{hCG}}$

$\begin{array}{lllll}0 & 0.01 & 0.1 & 1 & 0.1\end{array}$
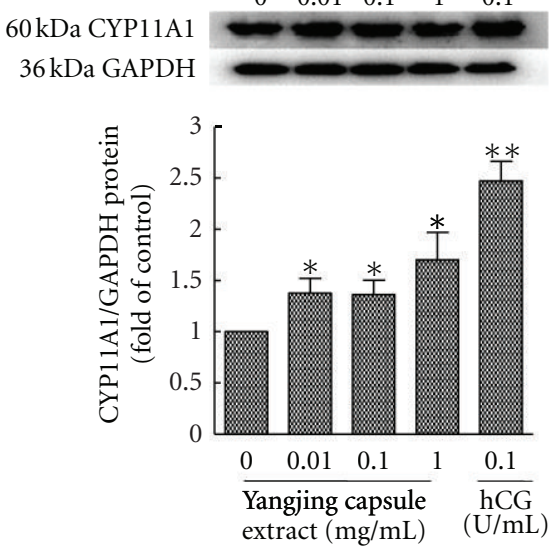

(b)

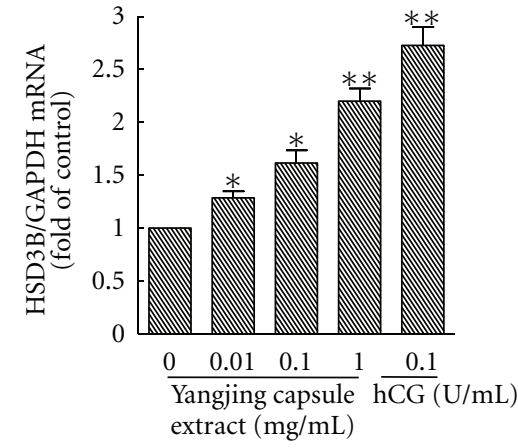

Yangjing $(\mathrm{mg} / \mathrm{mL})(\mathrm{UCG}$

$\begin{array}{lllll}0 & 0.01 & 0.1 & 1 & 0.1\end{array}$

$42 \mathrm{kDa}$ HSD3B

$36 \mathrm{kDa}$ GAPDH

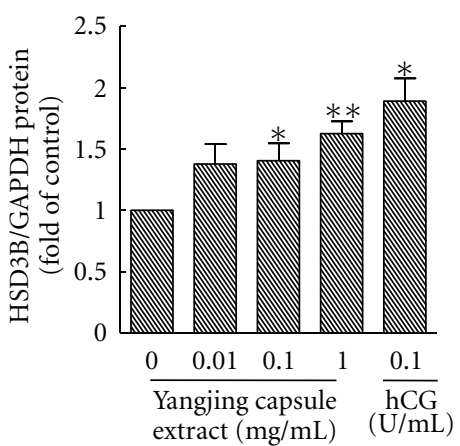

(c)

FIGURE 2: Effects of the Yangjing capsule extract on the expression of StAR (a), CYP11A1 (b), HSD3B (c) mRNAs and proteins in MLTC-1 cells. The Yangjing capsule extract was used to treat MLTC- 1 cells for $24 \mathrm{~h}$, and $0.1 \mathrm{U} / \mathrm{mL}$ hCG was added for $4 \mathrm{~h}$. Expression of mRNAs was detected by real-time RT-PCR. Expression of proteins was detected by Western blot. The data are expressed as the percentage of the control $(100 \%)$. The results are given as the means \pm SD from three independent experiments. Compared with the control, ${ }^{*} P<0.05, * * P<0.01$.

cells in G2/M phase showed no significant difference when compared with the controls $(P>0.05)$. In addition, the PI of MLTC- 1 cells showed differences at concentrations higher than $0.1 \mathrm{mg} / \mathrm{mL}$ (Figure 5(c)).

3.6. Effects of the Yangiing Capsule Extract on Cell Apoptosis and Caspase-3 Expression. To assess the effect of the Yangjing capsule extract on the apoptosis of MLTC-1 cells, the cells were treated for $48 \mathrm{~h}$ and examined using flow cytometry (Figure 6(a)). The apoptosis rate decreased after treatment with the Yangjing capsule extract, the survival rate increased (Figure 6(b)), and both changes were dosedependent $(P<0.05$ or $P<0.01)$. These results showed that the Yangjing capsule extract has a protective effect on MLTC1 cells.

The expression of caspase-3 is showed in Figures 6(c) and $6(\mathrm{~d})$. The expression of caspase- $3 \mathrm{mRNA}$ and protein decreased after treatment with the Yangjing capsule extract for $48 \mathrm{~h}$ in a dose-dependent manner $(P<0.05)$. This result suggested that the Yangjing capsule extract inhibited apoptosis by suppressing caspase- 3 expression.

\section{Discussion}

The Yangjing capsule has been used in the clinic for the treatment for male patients with infertility, $\mathrm{LOH}$ and sexual dysfunction. However, its mechanisms are still unclear. In this study, we found that the Yangjing capsule extract stimulated steroidogenesis and exerted a protective effect on Leydig cells.

It has been widely accepted that many Chinese medicines intended for kidney support can also regulate steroidogenesis and hormonal balance $[7,23]$. The Yangjing capsule extract increased testosterone production in MLTC-1 cells after $24 \mathrm{~h}$ of activation in a dose-dependent manner. Additionally, it affected testosterone production in concert with hCG. It is well known that LH and hCG are glycoproteins that contain polysaccharides [24]. Polysaccharides have been found in interstitial tissues as structural molecular forms that function by recognizing, connecting, or contacting molecules involved in cell interaction and communication [25]. Polysaccharides are also components of immunoglobulins, hormones, and enzymes [26]. The glycoprotein of LH/hCG plays an important role in association with the $\mathrm{LH}$ receptor to activate the signaling pathway for steroidogenesis [24]. It is 


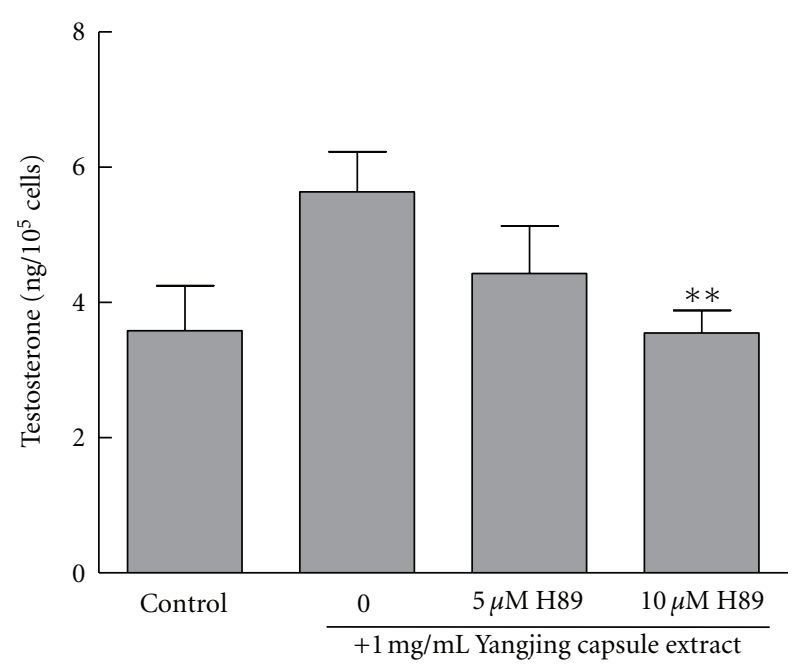

FIGURE 3: The effects of the Yanging capsule extract on testosterone production were inhibited by PKA inhibitor H89. The Yangjing capsule extract was used to treat cells combined with or without $5 \mu \mathrm{M}$ and $10 \mu \mathrm{M} H 89$ for an incubation period of $24 \mathrm{~h}$. The results are given as the means \pm SD from three independent experiments. Compared with treatment with the Yangjing capsule extract alone, ** $P<0.01$.

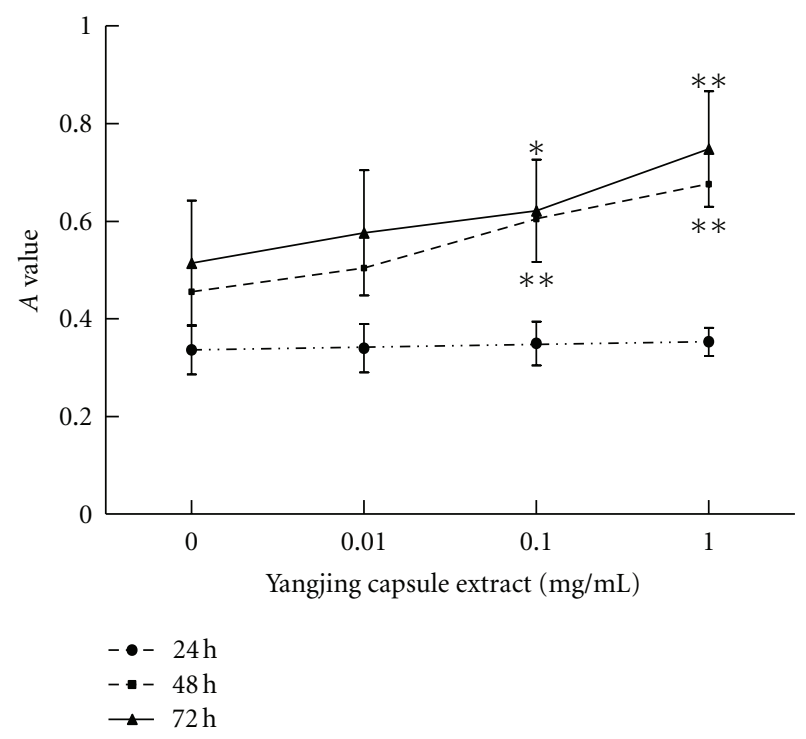

FIgURE 4: Effects of the Yangjing capsule extract on the viability of MLTC-1 cells. The Yangjing capsule extract was added to MLTC1 for $24-72 \mathrm{~h}$. Cell viability was analyzed by the MTT assay. The results are given as the means $\pm \mathrm{SD}$ from three independent experiments. Compared with control, ${ }^{*} P<0.05$, ${ }^{* *} P<0.01$.

possible that parts of the polysaccharides in the Yangjing capsule extract may be similar to LH in their structure and have the ability to recognize LH receptors on Leydig cells and then stimulate testosterone production. Moreover, it has been demonstrated that icariin, a flavonoid isolated from Herba Epimedii Brevicornus, has testosterone mimetic properties and therapeutic potential in the management of hypogonadism [27]. However, it remains to be elucidated whether these components participate in the critical function of steroidogenesis.

We also found that the Yangjing capsule extract significantly stimulated the expression of StAR, CYP11A1, and HSD3B mRNAs and proteins. hCG is well known to stimulate the cAMP-PKA signaling pathway to regulate steroidogenesis in Leydig cells in vivo and in vitro. We hypothesized that the Yangjing capsule induced testosterone production via the cAMP-PKA signaling pathway. This hypothesis was confirmed by the observation that H89, an inhibitor of the PKA pathway, significantly reduced the testosterone production induced by the Yangjing capsule extract. We can conclude that the Yangjing capsule extract most likely activated the cAMP-PKA signaling pathway to stimulate the expression of StAR, CYP11A1, and HSD3B, and then it increased testosterone production.

In addition to steroidogenesis, the Yangjing capsule extract significantly decreased apoptosis in cultured MLTC1 cells. Apoptosis in MLTC-1 cells was induced by serumfree medium. The Yanging capsule extract could increase cell viability in a time- and dose-dependent manner. In the flow cytometry analysis, the Yangjing capsule extract significantly decreased the number of cells in G0/G1 phase, increased the number of cells in S phase, and significantly decreased the number of apoptotic cells. Meanwhile, it decreased caspase3 expression in a dose-dependent manner. Therefore, the Yangjing capsule extract can exert a protective effect on Leydig cells in vitro. It is reported that polysaccharides exert antiapoptosis and antioxidative activities $[28,29]$. It has been demonstrated that Rhizoma Polygonati Sibirici polysaccharides were able to prevent apoptosis in hypoxic neurons through upregulation of $\mathrm{Bcl}-2$ protein expression, downregulation of Bax-2 protein expression and raising the ratio of $\mathrm{Bcl}-2 / \mathrm{Bax}$ [30]. Radix Rehmanniae preparata polysaccharides were clearly shown to promote the activity of SOD, CAT, and GSH-PX to perform anti-oxidant action [31], and they play a role in the nervous, endocrine, immune, and hematopoietic systems through their influence on cell proliferation and apoptosis [32]. Radix Astragali Mongolici polysaccharides promote hematopoiesis and thrombopoiesis in a mouse model due to their anti-apoptosis activity [33]. Finally, litchi polysaccharides have the potential to enhance antioxidant activity [34]. These factors may be responsible for the anti-apoptosis action of the Yangjing capsule on MLTC-1 cells. Additional studies of the mechanism of the Yangjing capsule are necessary because this innovative traditional Chinese medicine has complex active ingredients.

Restoration of the endogenous hormonal balance and stimulation of testosterone production could be one of the mechanisms of Yangjing capsule when used to treat male hypogonadism, $\mathrm{LOH}$, sexual dysfunction, and infertility. We found that the Yangjing capsule extract promoted testosterone production in Leydig cells through the activation of the cAMP-PKA signaling pathway, and it stimulated the expression of StAR, CYP11A1, and HSD3B. Endogenous testosterone exerts its action more effectively than exogenous androgen in treatment of $\mathrm{LOH}$, avoiding the adverse side effects due to superphysiological and unstable hormone 


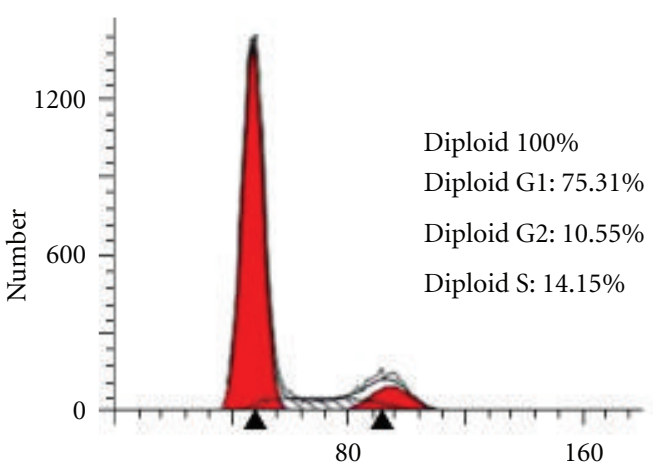

Channels (FL2-A)

Yangjing capsule extract $(0 \mathrm{mg} / \mathrm{mL})$

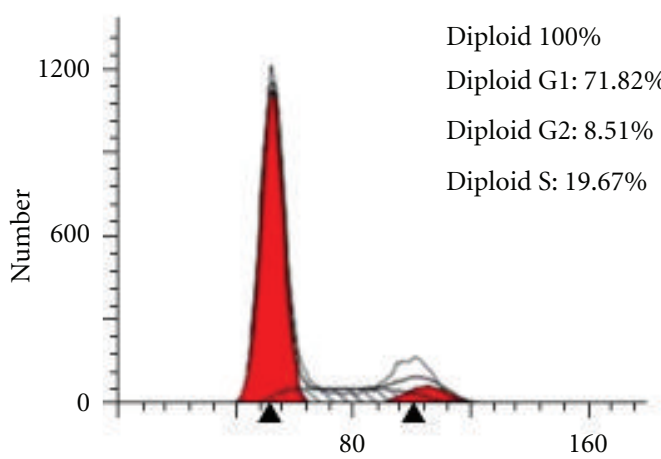

Channels (FL2-A)

Yangjing capsule extract $(0.1 \mathrm{mg} / \mathrm{mL})$

$$
\begin{aligned}
& \text { - Diploid G1 } \\
& \text { - Diploid G2 } \\
& \text { «iploid S }
\end{aligned}
$$

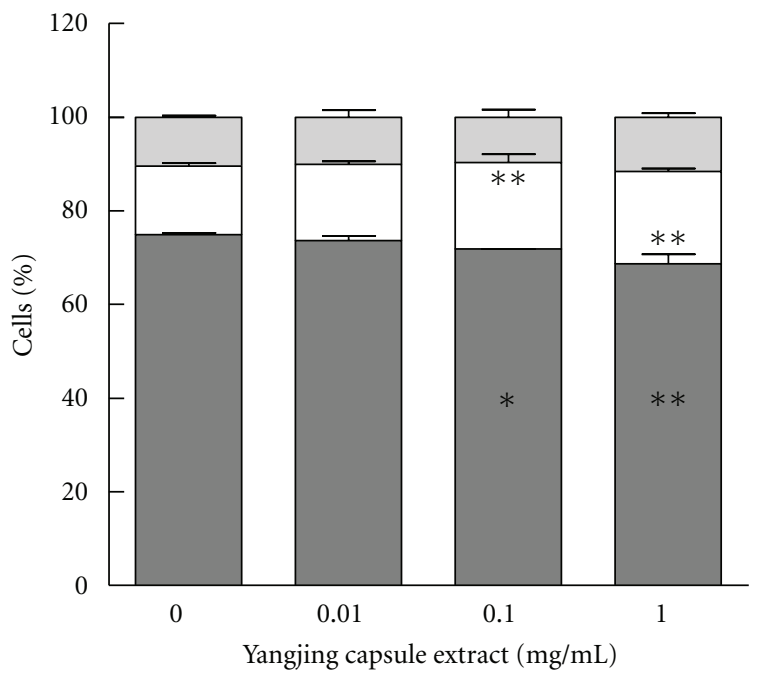

Yangjing capsule extract $(\mathrm{mg} / \mathrm{mL})$
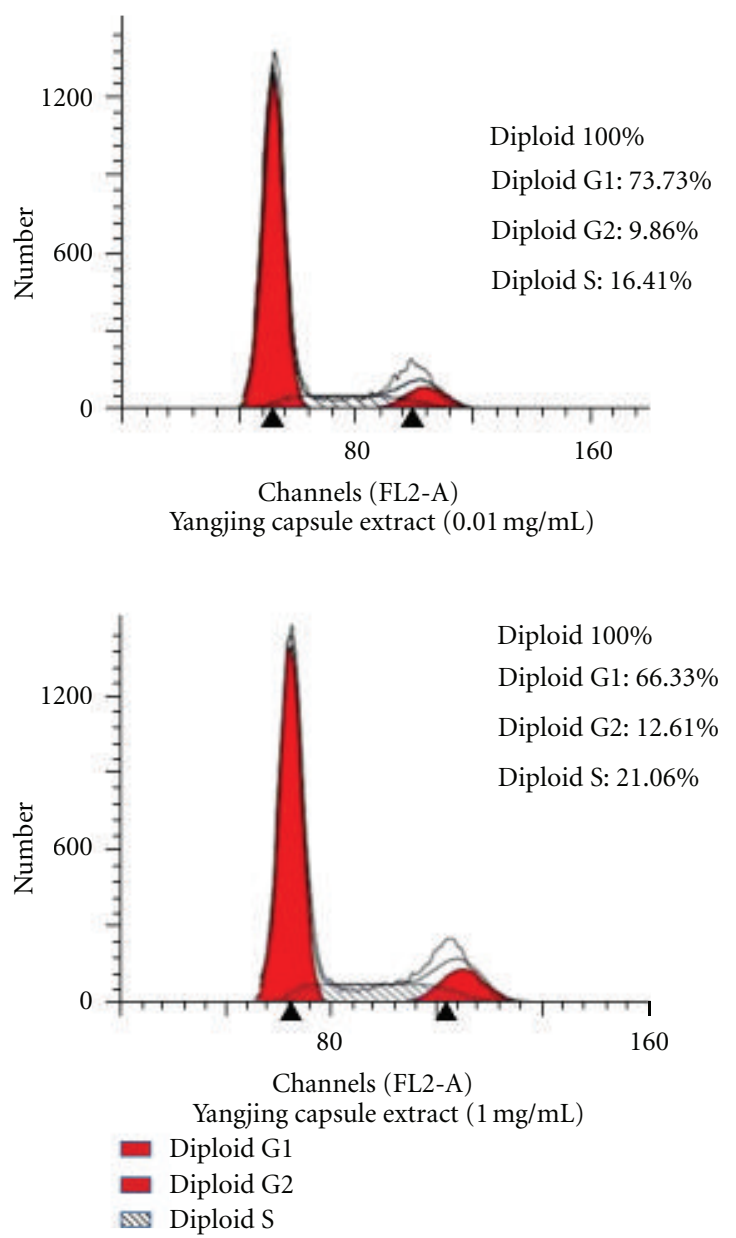

(a)

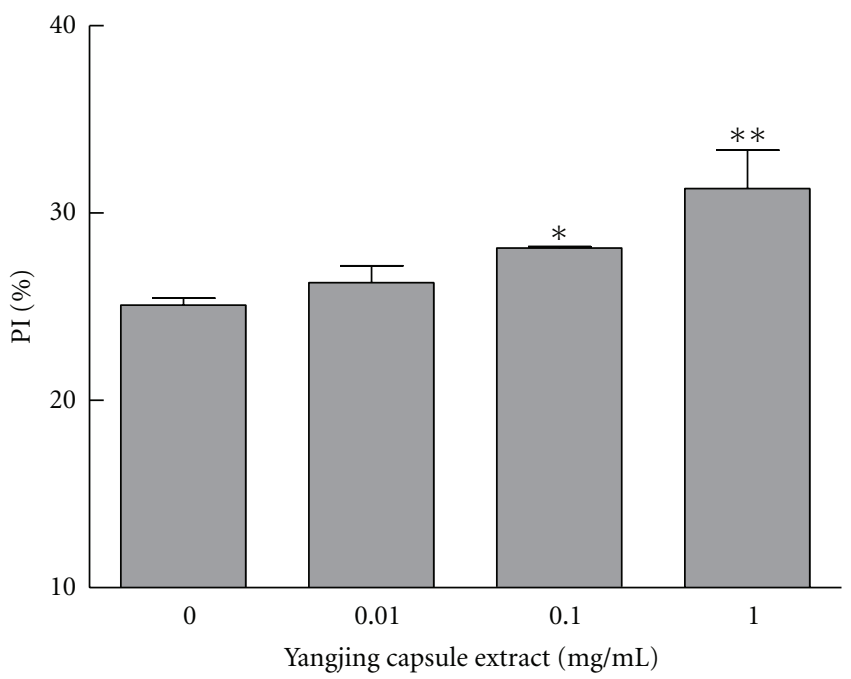

G0/G1

(b)

(c)

Figure 5: Effects of the Yangjing capsule extract on the MLTC-1 cell cycle. The Yangjing capsule extract was added to MLTC-1 cells for $48 \mathrm{~h}$ without serum. The cells were analyzed by flow cytometry. (a) The percentage of cells in each cell cycle stage was analyzed using flow cytometry after staining with propidium iodide. (b) The ratios of cells in the different phases are represented as percentage. (c) The effect of the Yangjing capsule extract on the PI of MLTC-1 cells. The results are given as the means \pm SD from three independent experiments. Compared with control, ${ }^{*} P<0.05,{ }^{* *} P<0.01$. 

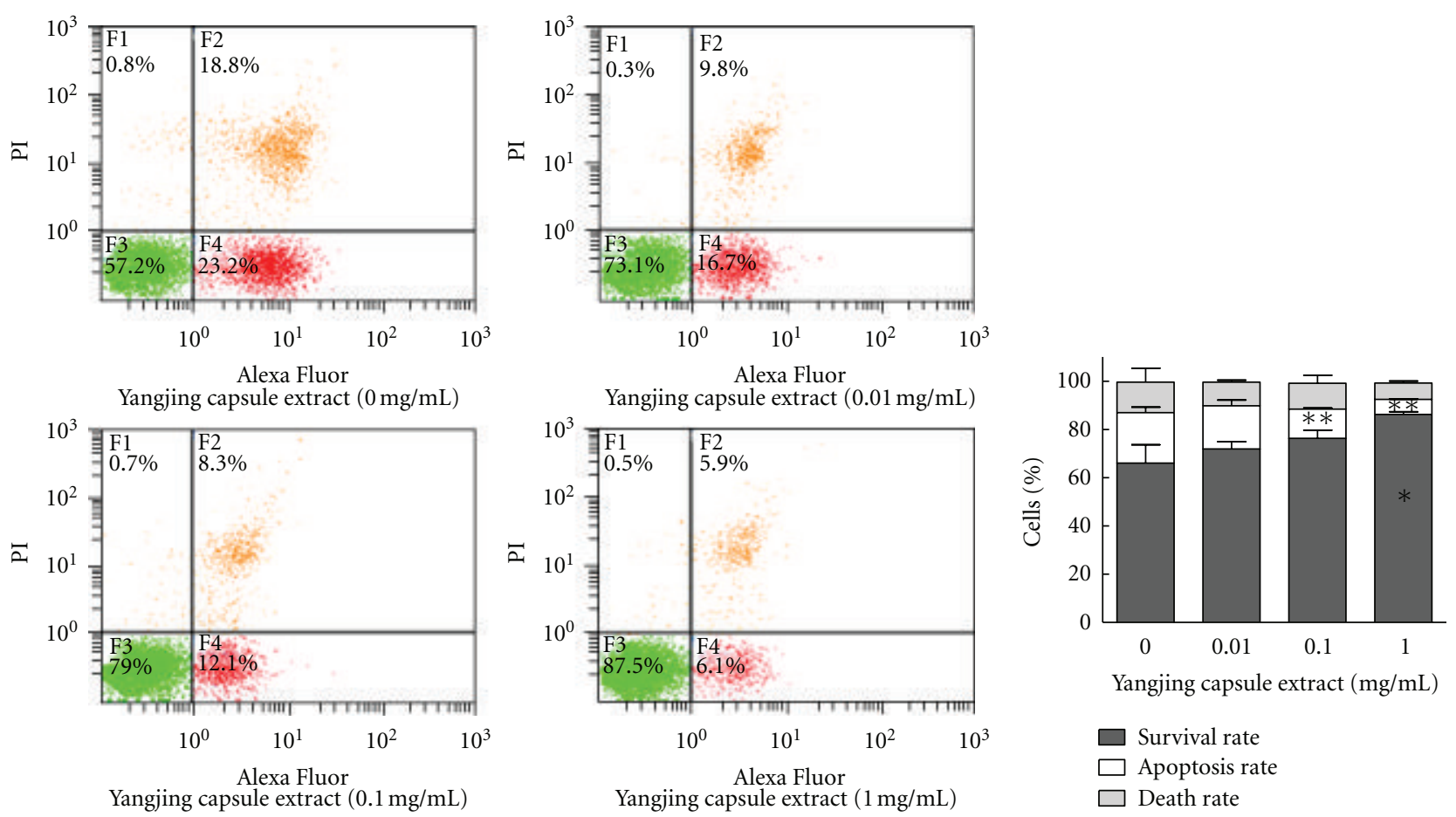

(a)

(b)

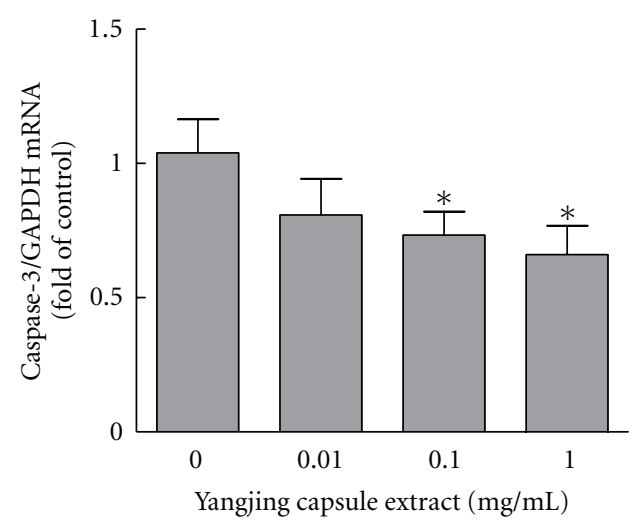

(c)

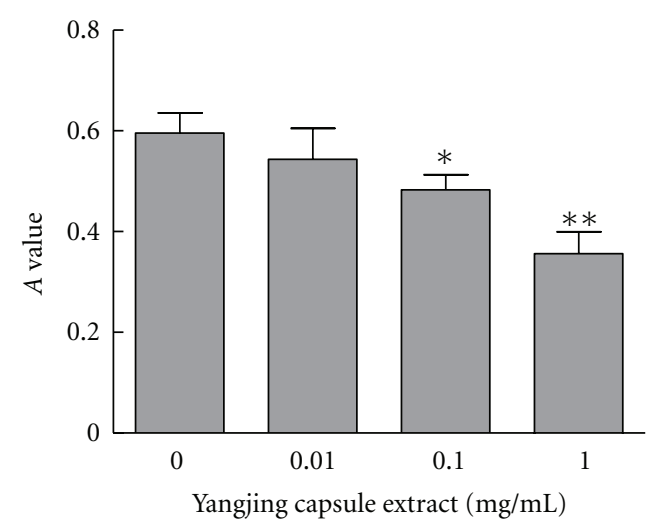

(d)

Figure 6: Effects of the Yangjing capsule extract on apoptosis and caspase-3 expression in MLTC-1 cells. The Yangjing capsule extract was added to MLTC-1 cells for $48 \mathrm{~h}$ without serum. The cells were collected and analyzed using flow cytometry. The expression of caspase- 3 mRNA and protein was detected by real-time RT-PCR and a colorimetric assay. (a) The percentages of viable cells are shown in the lower left quadrant, and the percentages of apoptotic cells are shown in the lower right quadrant. (b) The ratios of the above cells are represented as percentages. (c) The effect of the Yangjing capsule extract on expression of caspase-3 mRNA. (d) The effect of the Yanging capsule extract on caspase- 3 protein activity. The determination of caspase- 3 activity was performed using a caspase- 3 colorimetric protease assay kit. The results are given as the means $\pm \mathrm{SD}$ from three independent experiments. Compared with control, ${ }^{*} P<0.05,{ }^{* *} P<0.01$.

concentrations. In addition, we found that the Yangjing capsule extract had protective effects on Leydig cells. The increased apoptosis of Leydig cells is one of the pathophysiological causes of hypogonadism and LOH [13]. The testes of men with $\mathrm{LOH}$ exhibit testicular fibrosis, insufficient blood supply, and reduced quantities of Leydig cells [35]. The aged Leydig cells are mostly vacuolated, and multinucleated and contain abundant lipid droplets [36] due to the increased activation of apoptosis factors, including caspase-3 [37], and DNA fragmentation [38]. The Yangjing capsule decreased caspase-3 expression and decreased apoptosis in Leydig cells. Therefore, it represents a testicular protective treatment for LOH.

In conclusion, we found that the Yangjing capsule extract effectively promoted testosterone production in Leydig cells while exerting protective effects on Leydig cells. The Yangjing capsule may be an alternative medicine for the treatment of diseases characterized by insufficient testosterone, such as male infertility, hypogonadism, and LOH. Further study will improve its clinical efficacy. 


\section{Acknowledgments}

This work was supported by Chinese Nature and Science Program $(81273760,81170559)$ and a Postgraduate Innovation Program of the Jiangsu Province Education Department. The authors thank the State Key Laboratory of Reproductive Medicine, the Clinical Center of Reproductive Medicine, and the Nanjing Medical University for providing laboratory and technological assistance.

\section{References}

[1] E. J. Richmond and A. D. Rogol, "Male pubertal development and the role of androgen therapy," Nature Clinical Practice Endocrinology and Metabolism, vol. 3, no. 4, pp. 338-344, 2007.

[2] M. R. Pinsky and W. J. G. Hellstrom, "Hypogonadism, ADAM, and hormone replacement," Therapeutic Advances in Urology, vol. 2, no. 3, pp. 99-104, 2010.

[3] M. Rabijewski and W. Zgliczyński, "Pathogenesis, evaluation and treatment of hypogonadism in men," Endokrynologia Polska, vol. 60, no. 3, pp. 222-233, 2009.

[4] N. Bassil, S. Alkaade, and J. E. Morley, "The benefits and risks of testosterone replacement therapy: a review," Therapeutics and Clinical Risk Management, vol. 5, no. 1, pp. 427-448, 2009.

[5] S. Kliesch, "Testosterone and infertility," Der Urologe A, vol. 49, no. 1, pp. 32-36, 2010.

[6] W. G. Ma and J. M. Jia, "The effects and prospects of the integration of traditional Chinese medicine and Western medicine on andrology in China," Asian Journal of Andrology, vol. 13, no. 4, pp. 592-595, 2011.

[7] H. Q. Jin, F. Jiang, D. M. Deng, W. X. Chen, G. Z. Yang, and T. Q. Zhuang, "Regulatory effect of Bushenfang on the serum testosterone level of naturally aging rats and its mechanism," Zhonghua Nan Ke Xue, vol. 17, no. 8, pp. 758-762, 2011.

[8] B. F. Jin, Y. F. Huang, and X. H. Lu, "Clinical observation of the treatment of male sexual dysfunction by yangjingjiaonang," Zhonghua Nan Ke Xue, vol. 12, no. 3, pp. 272-276, 2006.

[9] B. F. Jin, Y. F. Huang, X. Y. Yang, X. J. Shang, X. H. Lu, and X. L. Wang, "Clinical observation on treatment of oligosperntatisn with yangjing capsule," Journal of Nanjing TCM University, vol. 22, no. 5, pp. 286-289, 2006.

[10] B. Jin, Y. Huang, X. Xia, X. Wang, X. Yang, and Z. Zhou, "Effect of Yangiing capsule and Xinxibao on sperm DNA integrity of patients with male infertility," Chinese Journal of Andrology, vol. 20, no. 12, pp. 45-49, 2006.

[11] M. L. Dufau, "Endocrine regulation and communicating functions of the Leydig cell," Annual Review of Physiology, vol. 50, pp. 483-508, 1988 .

[12] S. G. Haider, "Leydig cell steroidogenesis: unmasking the functional importance of mitochondria," Endocrinology, vol. 148, no. 6, pp. 2581-2582, 2007.

[13] K. Henriksen, H. Hakovirta, and M. Parvinen, "Testosterone inhibits and induces apoptosis in rat seminiferous tubules in a stage-specific manner: in situ quantification in squash preparations after administration of ethane dimethane sulfonate," Endocrinology, vol. 136, no. 8, pp. 3285-3291, 1995.

[14] M. A. Helal, H. Mehmet, N. S. B. Thomas et al., "Ontogeny of human fetal testicular apoptosis during first, second, and third trimesters of pregnancy," Journal of Clinical Endocrinology and Metabolism, vol. 87, no. 3, pp. 1189-1193, 2002.

[15] I. Budihardjo, H. Oliver, M. Lutter, X. Luo, and X. Wang, "Biochemical pathways of caspase activation during apoptosis,"
Annual Review of Cell and Developmental Biology, vol. 15, pp. 269-290, 1999.

[16] P. Saikumar, Z. Dong, V. Mikhailov, M. Denton, J. M. Weinberg, and M. A. Venkatachalam, "Apoptosis: definition, mechanisms, and relevance to disease," American Journal of Medicine, vol. 107, no. 5, pp. 489-506, 1999.

[17] S. T. Kao, C. C. Yeh, C. C. Hsieh et al., "The Chinese medicine Bu-Zhong-Yi-Qi-Tang inhibited proliferation of hepatoma cell lines by inducing apoptosis via G0/G1 arrest," Life Sciences, vol. 69, no. 13, pp. 1485-1496, 2001.

[18] B. Hu, H. M. An, K. P. Shen, and Q. Du, "Effects of Tenglong Buzhong Decoction on proliferation and apoptosis of human colon carcinoma cell line LS174T," Zhong Xi Yi Jie He Xue Bao, vol. 8, no. 6, pp. 575-580, 2010.

[19] Y. Wang, L. Song, X. Hong et al., "Low concentrations mono-butyl phthalate stimulates steroidogenesis by facilitating steroidogenic acute regulatory protein expression in mouse Leydig tumor cells (MLTC-1)," Chemico-Biological Interactions, vol. 164, no. 1-2, pp. 15-24, 2006.

[20] Y. Fu, Z. Zhang, G. Zhang et al., "Adenovirus-mediated gene transfer of tissue factor pathway inhibitor induces apoptosis in vascular smooth muscle cells," Apoptosis, vol. 13, no. 5, pp. 634-640, 2008.

[21] S. Abid-Essefi, I. Baudrimont, W. Hassen et al., "DNA fragmentation, apoptosis and cell cycle arrest induced by zearalenone in cultured DOK, Vero and Caco-2 cells: prevention by Vitamin E," Toxicology, vol. 192, no. 2-3, pp. 237-248, 2003.

[22] A. R. Doo, S. N. Kim, J. Y. Park et al., "Neuroprotective effects of an herbal medicine, Yi-Gan San on MPP+/MPTP-induced cytotoxicity in vitro and in vivo," Journal of Ethnopharmacology, vol. 131, no. 2, pp. 433-442, 2010.

[23] Z. Quan and J. Wei, "The research of traditional Chinese drug kidney-reinforcing on increasing testosterone level-based on Meta analysis of 7 clinical contrast experiments," Medical Information, vol. 18, no. 9, pp. 1153-1155, 2005.

[24] P. Pigny, A. Berault, D. Dewailly, and A. Boersma, "Glycoprotein hormones, glycosylation and biological activity," Annales de Biologie Clinique, vol. 50, no. 8, pp. 557-564, 1992.

[25] E. Ruoslahti, "Proteoglycans in cell regulation," Journal of Biological Chemistry, vol. 264, no. 23, pp. 13369-13372, 1989.

[26] A. J. Lapthorn, D. C. Harris, A. Littlejohn et al., "Crystal structure of human chorionic gonadotropin," Nature, vol. 369, no. 6480, pp. 455-461, 1994.

[27] Z. B. Zhang and Q. T. Yang, "The testosterone mimetic properties of icariin," Asian Journal of Andrology, vol. 8, no. 5, pp. 601-605, 2006.

[28] Y. Zhou and Y. Geng, "Study on relationship between polysaccharides and cell apoptosis," Chinese Traditional and Herbal Drugs, vol. 38, no. 4, pp. 623-626, 2007.

[29] Q. M. Liu and J. G. Jiang, "Antioxidative activities of medicinal plants from TCM," Mini-Reviews in Medicinal Chemistry, vol. 12, no. 11, pp. 1154-1172, 2012.

[30] G. Z. Hu, R. Q. Nie, Y. S. Xiao, J. Zhang, Z. Wen, and D. F. Wu, "Influence of polygonatum polysaccharide on apoptosis of primary cultured neonate rat cerebral cortical neurons caused by hypoxia," Pharmacology and Clinics of Chinese Materia Medica, vol. 21, no. 4, pp. 37-39, 2005.

[31] M. S. Miao, Y. H. Sun, and X. Y. Fang, "Studies on antiaxidation capacity of radix rehmaniae preparate polysaccharide in aged model mice," Chinese Journal of Information on Traditional Chinese Medicine, vol. 9, no. 10, pp. 32-33, 2002.

[32] Y. Cui, "The progress in pharmacological research of rchmannia glutnosa polysaccharides," Chinese Journal of Natural Medicines, vol. 2, no. 3, pp. 186-188, 2000. 
[33] F. Kong, M. Zhang, S. Liao, S. Yu, J. Chi, and Z. Wei, "Antioxidant activity of polysaccharide-enriched fractions extracted from pulp tissue of litchi chinensis sonn," Molecules, vol. 15, no. 4, pp. 2152-2165, 2010.

[34] L. Chang, J. Li, F. Y. Meng et al., "Polysaccharides from the root of Angelica sinensis promotes hematopoiesis and thrombopoiesis through the PI3K/AKT pathway," BMC Complementary and Alternative Medicine, vol. 10, article 79, 2010.

[35] S. W. J. Lamberts, A. W. Van Den Beld, and A. J. Van Der Lely, "The endocrinology of aging," Science, vol. 278, no. 5337, pp. 419-424, 1997.

[36] S. G. Haider, "Cell Biology of Leydig Cells in the Testis," International Review of Cytology, vol. 233, pp. 181-241, 2004.

[37] F. Matsuda-Minehata, N. Inoue, Y. Goto, and N. Manabe, "The regulation of ovarian granulosa cell death by proand anti-apoptotic molecules," Journal of Reproduction and Development, vol. 52, no. 6, pp. 695-705, 2006.

[38] A. G. Porter and R. U. Jänicke, "Emerging roles of caspase-3 in apoptosis," Cell Death and Differentiation, vol. 6, no. 2, pp. 99-104, 1999. 


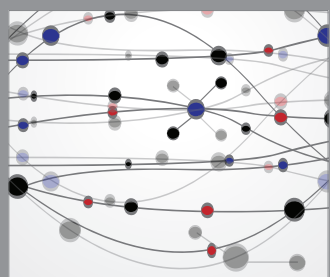

The Scientific World Journal
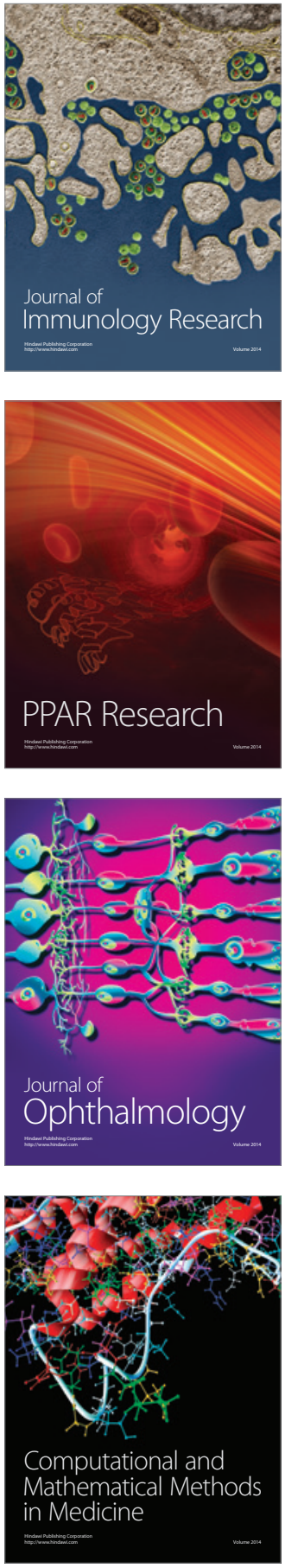

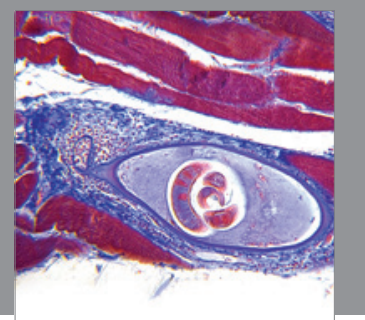

Gastroenterology

Research and Practice
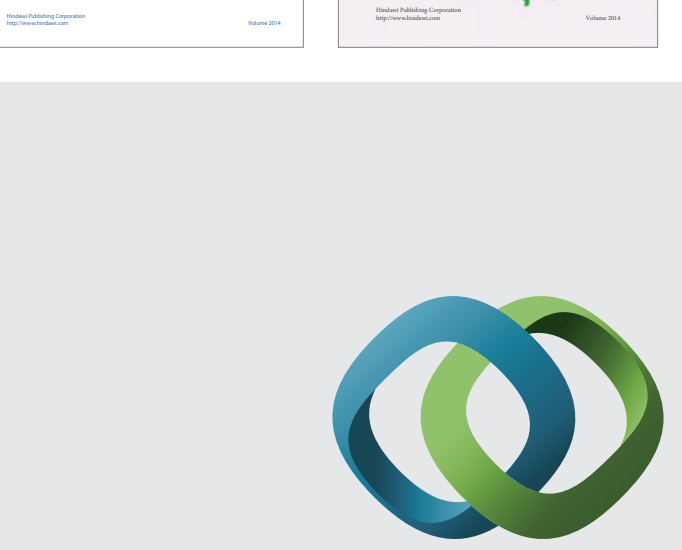

\section{Hindawi}

Submit your manuscripts at

http://www.hindawi.com
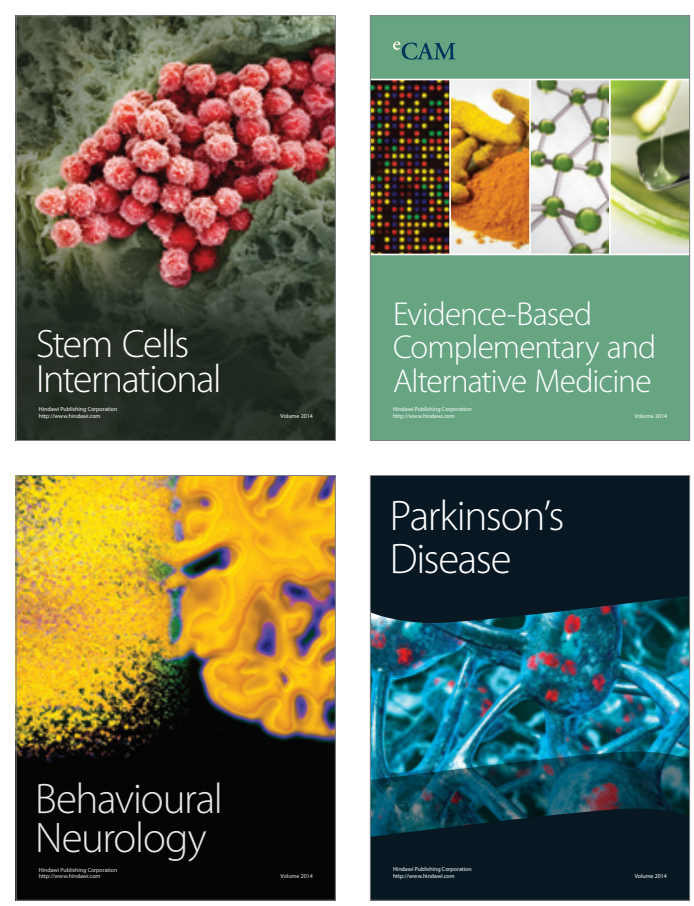

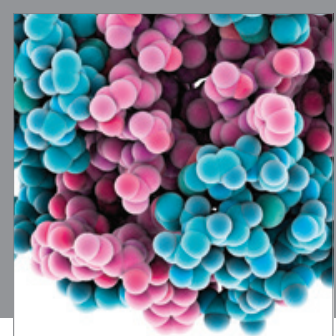

Journal of
Diabetes Research

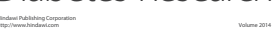

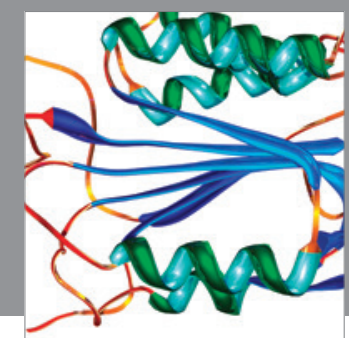

Disease Markers
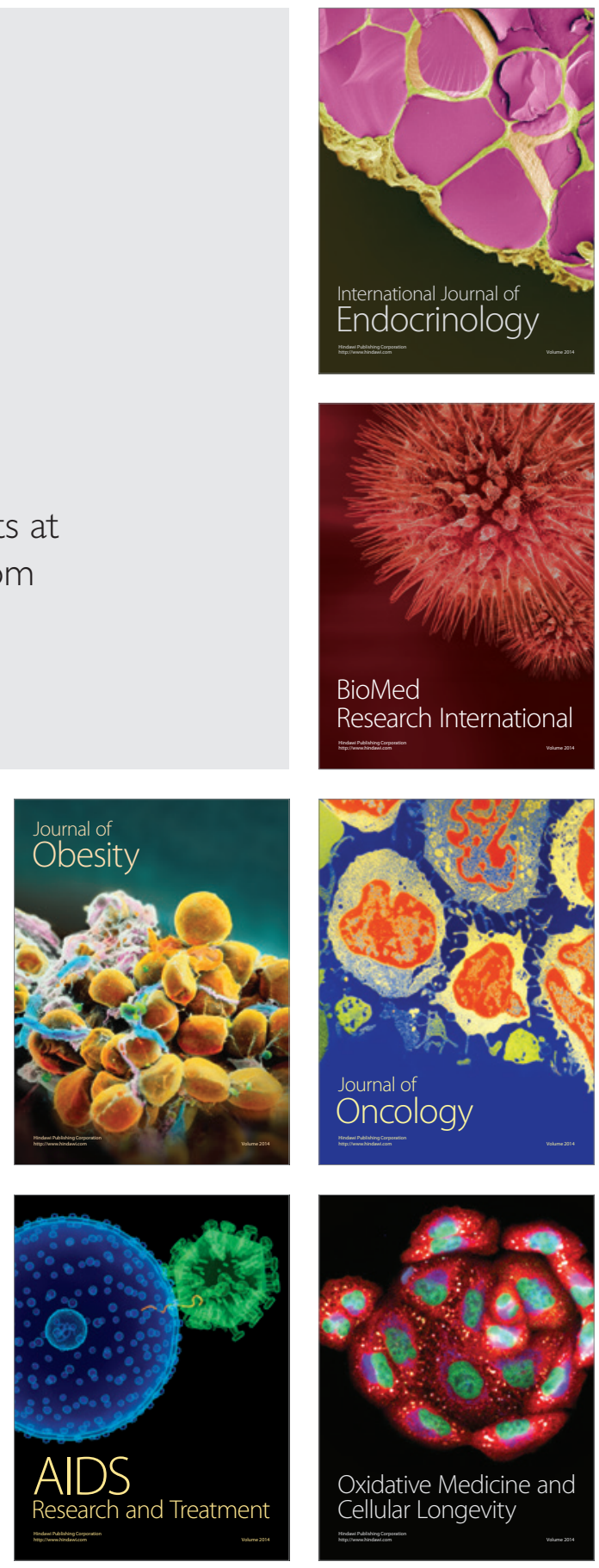